\title{
Pengaruh Pemberian Vitamin E terhadap Morfologi Testis Tikus Strain Wistar (Rattus novergicus) dengan Diabetes Melitus Tipe I
}

T. Ronasky ${ }^{1}$, Jufriady Ismy ${ }^{2}$ and Dasrul Dasrul ${ }^{3}$

\author{
${ }^{1}$ Program Pendidikan Dokter Spesialis Ilmu Bedah, Fakultas Kedokteran Universitas Syiah Kuala/ Rumah \\ Sakit Umum dr. Zainoel Abidin Banda Aceh. \\ ${ }^{2}$ Divisi Urologi, Departemen Bedah Fakultas Kedokteran Universitas Syiah Kuala/ Rumah Sakit Umum \\ dr. Zainoel Abidin Banda Aceh. \\ ${ }^{3}$ Staf Dosen Kedokteran Hewan, Fakultas Kedokteran Hewan Universitas Syiah Kuala/ Rumah Sakit \\ Umum dr. Zainoel Abidin Banda Aceh.
}

\begin{abstract}
Abstrak
Latar Belakang. Diabetes melitus (DM) adalah penyakit metabolik dengan karakteristik hiperglikemia yang terjadi karena kelainan sekresi insulin, kerja insulin, atau kedua-duanya. ${ }^{1}$ Penyakit ini dilaporkan terjadi pada 9\% laki-laki dan 7,9\% wanita. Laporan Center of disease control (CDC) menyebutkan tahun 2014 terdapat 8,1 juta orang tidak terdiagnosa DM dan 29,1 juta mengalami penyakit ini di Amerika Serikat. ${ }^{2}$ Pada penderita diabetes dapat terjadi kerusakan jangka panjang, disfungsi, dan kegagalan organ yang berbeda, terutama mata (diabetes retinopathy), ginjal (nefropati diabetik), saraf (neuropati diabetes), jantung (infark miokard) dan pembuluh darah (aterosklerosis) dan infertilitas. Laporan insiden infertilitas terkait DM terjadi pada $9 \%$ orang dewasa berusia $>18$ tahun mengalami akibat difungsi endokrin spermatogenesis. Vitamin E berperan sebagai antioksidan eksogen (non-enzimatis) yang dapat melindungi kerusakan membran biologis akibat radikal bebas. Vitamin E melindungi asam lemak tidak jenuh pada membran fosfolipid. Secara partikular, vitamin E juga penting dalam mencegah peroksidasi membran asam lemak tak jenuh.

Metode. Penelitian ini adalah penelitian eksperimental dengan menggunakan rancangan posttest only control group design secara laboratorium eksperimental. Rancangan penelitian ini dipilih berdasarkan konsep bahwa setiap unit dari populasi adalah homogen dan memiliki karakteristik yang sama. Pembagian sampel dilakukan secaraacak (random assignment). Pada kelompok eksperimen perlakuanlangsung diberikan stimulus dan pengamatan akhir sementara
\end{abstract}


pada kelompok kontrol digunakan sebagai pembanding dari kelompok perlakuan.

Hasil. Rata-rata diamater tubulus seminiferus testes tikus pada masing-masing kelompok perlakuan menunjukkan angka yang bervariasi. Rata-rata diamater tubulus seminiferus testes tikus pada perlakuan kontrol negatif $(\mathrm{KN})$ adalah $261,57 \pm 5,72 \mu \mathrm{m}$, kemudian mengalami penurunan menjadi $241,18 \pm 18,53 \mu \mathrm{m}$, pada perlakuan tikus DM yang diinduksi aloksan (KP), dan mengalami peningkatan kembali pada perlakuan tikus DM yang dinduksi aloksan dan vitamin E dengan dosis $100 \mathrm{mg} / \mathrm{kgbb} /$ hari (P1), dan $200 \mathrm{mg} / \mathrm{kgbb} /$ hari (P2), secara berturut-turut adalah $265,92 \pm 15,97 \mu m$ dan $271,41 \pm 24,79 \mu m$.

Kesimpulan. Berdasarkan uji statistik Analysis of variance (ANOVA) one way didapatkan nilai signifikannya p $0,039<0,05$, maka dapat ditarik kesimpulan bahwa perlakuan pemberian vitamin E (P1 dan P2) berpengaruh secara signifikan terhadap diameter tubulus seminiferus testis tikus putih diabetes.

Kata Kunci : Vitamin E, Histomorfometri Testis Tikus Putih (strain wistar), Dm Tipe 1. 


\title{
The Effect of Vitamin E Supplementation to the Morphology of Wistar Strain Rat Testis
}

\section{(Rattus Novergicus) with Diabetes Mellitus Type I}

T. Ronasky ${ }^{1}$, Jufriady Ismy ${ }^{2}$ and Dasrul Dasrul ${ }^{3}$

\begin{abstract}
Background. Diabetes mellitus (DM) is a metabolic disease with characteristics of hyperglycemia that occurs due to abnormal insulin secretion, insulin action, or both. $\frac{1}{1}$ This disease is reported to occur in $9 \%$ of male and $7.9 \%$ of female. The Center of Disease Control (CDC) report states that there were 8.1 million undiagnosed people in 2014 and 29.1 million had this disease in the United States. $\stackrel{2}{=}$ In diabetics can occur long-term damage, dysfunction, and failure of different organs, especially the eyes (diabetic retinopathy), kidney (diabetic nephropathy), nerves (diabetic neuropathy), heart (myocardial infarction) and blood vessels (atherosclerosis) and infertility. Reports of incident DM-related infertility occur in $9 \%$ of adults $>18$ years of age experience the consequences endocrine dysfunction spermatogenesis.Vitamin E plays a role as antioxidant exogenous (non- enzymatic ) which can protect damage membrane biological consequence radical free.Vitamin E protects acid fat not saturated on membrane phospholipid. In a manner particular, vitamin $\mathrm{E}$ too important in prevent peroxidation membrane acid fat not saturated.
\end{abstract}

Method. This research is experimental research with use design post-test only control group design in laboratory experimental. Design research this selected based on concept that each unit from population is homogeneous and have the same characteristics. Division sample do randomized (random assignment). On group experiment treatment immediately given stimulus and observation end while on group control used as comparison from group treatment .

Results. The average seminiferous tubule of rat testis in each treatment group showed variable numbers. The average seminiferous tubule diameters of rat testes in the negative control treatment $(\mathrm{KN})$ were $261.57 \pm 5.72 \mu \mathrm{m}$, then decreased to $241.18 \pm 18.53 \mu \mathrm{m}$, in the treatment of DM mice induced by alloxan (KP), and experienced a re-increase in the treatment of rat DM induced by alloxan and vitamin E with a dose of $100 \mathrm{mg} / \mathrm{kg} /$ day (P1), and $200 \mathrm{mg} / \mathrm{kg} /$ day (P2), respectively is $265.92 \pm 15.97 \mu m$ and $271.41 \pm 24.79 \mu m$. 
Conclusion. Based on one way Analysis of variance (ANOVA) statistical test, the significant of $\mathrm{p}$ value was $0.039<0.05$, it can be concluded that the treatment of vitamin E (P1 and P2) significantly affected the diameter of seminiferous tubules in testicular diabetic of white rats.

Keywords: Vitamin E, Testicular Rats Histomorphometry White (Wistar strain), Dm Type 1. 


\section{Pendahuluan}

Diabetes melitus (DM) adalah penyakit atau gangguan metabolik yang ditandai dengan peningkatan kadar glukosa di dalam darah (hyperglikemia) yang terjadi karena kurangnya sekresi dari insulin, kerja insulin, ataupun keduanya ${ }^{1,2}$. Penyakit diabetes melitus ini dilaporkan terjadi pada laki-laki sebanyak 9\% dan wanita sebanyak $7,9 \% \quad 2$. Menurut International Diabetes Federation (IDF) pada tahun 2015 terdapat 415 juta orang mengalami diabetes dan diperkirakan akan meningkat mencapai 642 juta orang pada tahun 2040. ${ }^{3}$ Sedangkan di Indonesia sendiri ada 10,2 juta kasus diabetes melitus pada usia dengan rentangan 18-99 tahun dan 10 juta kasus pada rentang usia 18-79 tahun. ${ }^{4}$ Selain itu diabetes mellitus ini sangat penting, karena dapat menyebabkan komplikasi yang ditimbulkannya seperti kegagalan fungsi seksual yang menyebabkan infertilitas. ${ }^{5}$
Kegagalan fungsi seksual (disfungsi seksual) pada laki-laki sering ditemukan sebagai komplikasi diabetes mellitus lanjut. Pada lakilaki disfungsi seksual ini dapat berupa menurunnya libido dan disfungsi ereksi. ${ }^{6}$ Disfungsi ereksi pada penderita diabetes meningkat $25 \%$ di atas usia 35 tahun dan $70 \%$ sesudah usia 60 tahun, serta $30 \%$ penderita diabetes mengalami infertilitas. ${ }^{7,8}$ Konsensus pengelolaan diabetes melitus di Indonesia menyatakan prevalensi infertilitas pada penderita diabetes melitus yang diderita lebih dari 10 tahun cukup tinggi. ${ }^{8,9}$

Beberapa peneliti lain menyatakan bahwa infertilitas pada penderita diabetes mellitus juga dapat disebabkan oleh gangguan fungsi jalur hipofisis pituitary gonad, regulasi hormon testosterone yang disertai gangguan proses spermatogenesis, perubahan morfologi spermatozoa, penurunan jumlah sel Leydig, penurunan produksi dan kualitas spermatozoa. ${ }^{10,11}$ 
Selain itu, dampak yang ditimbulkan akibat penyakit diabetes melitus, terutama pada organ testis diantaranya adalah pengecilan ukuran serta berat testis, peningkatan abnormalitas pada spermatogenesis yang ditandai dengan menurunnya jumlah sperma yang dihasilkan. ${ }^{11,12}$ Peningkatan jumlah sel yang mengalami apoptosis pada sel germinal (terutama spermatogonium dan spermatosit) dalam tubulus seminiferus telah dilaporkan juga terjadi pada hewan uji tikus diabetes. ${ }^{13,14}$

Beberapa peneliti membuktikan faktor utama pemicu terjadinya gangguan disfungsi seksual dan infertilitas pada penderita diabetes mellitus adalah akibat adanya produksi reactive oxygen spesies (ROS) yang berlebihan, sehingga terjadi ketidakseimbangan antara produksi ROS dengan kapasitas total antioksidan dalam tubuh yang dikenal dengan istilah stress oksidatif $8,15,16,17$. Stres oksidatif adalah peristiwa dimana peningkatan produksi ROS yang berupa molekul reaktif, yang muncul melalui suatu reaksi biokimiawi dari sel normal merusak membran dan mitokondria DNA, karbohidrat, protein dan lipid sel, yang selanjutnya menyebabkan berbagai gangguan fungsi tubuh diantaranya adalah organ testis ${ }^{18}$. Pada laporan studi populasi pasien dengan obesitas dan kontrol glikemik yang buruk, diperoleh pola jumlah sperma, volume testis, motilitas sperma dan morfologi juga telah dilaporkan mengalami abnormalitas. ${ }^{9,19}$ Soudami dkk juga menjelaskan bahwa terjadi perubahan progresif struktur epididymis akibat DM dimana diameter corpus, lumen epididymis lebih kecil dibandingkan hewan coba yang tidak DM dan mendapatkan terapi insulin. ${ }^{21}$

Stres oksidatif dalam tubuh pada dasarnya dapat diatasi oleh antioksidan endogen seperti Superoksida Dismutase (SOD), Katalase (Cat) dan Glutation peroksidase (GPx) dengan cara melindungi jaringan dari kerusakan oksidatif yang disebabkan oleh senyawa oksigen reaktif. Akan tetapi jika senyawa oksigen reaktif berlebih dalam tubuh atau melebihi batas kemampuan proteksi antioksidan seluler, maka dibutuhkan antioksidan tambahan dari luar atau antioksidan eksogen, salah satunya vitamin E. ${ }^{17,22,23}$

Peranan vitamin ini sebagai antioksidan untuk infertilitas terkait disfungsi testis dan spermatozoa terjadi karena kemampuannya sebagai scavenger/ pembersih radikal bebas dengan cara menghambat peroksidase lipid sehingga berperan dalam mencegah 
berlangsungnya reaksi peroksidasi lipid yang merusak testis dan spermatogenesis. ${ }^{22}$ Dilaporkan bahwa pencegahan peroksidase lipid mampu memperbaiki fungsi testis dan meningkatkan jumlah sperma disertai penurunan persentase sperma yang berbentuk abnormal. $^{23,24}$ Pemberian vitamin E 100 $\mathrm{mg} / \mathrm{kgBB} /$ hari mampu memperbaiki kualitas spermatozoa yang diisolasi dari epididymis dan tubulus seminiferous pada model studi stres oksidatif yang di induksi arsenik. ${ }^{25}$ Namun sampai saat ini belum ada penelitian yang menjelaskan secara spesifik perubahan mikroarsitektur morfologi testis jaringan secara spesifik pada epididymis, dan tubulus seminiferous yang mendapat terapi vitamin $\mathrm{E}$ pada kondisi diabetes melitus. Berdasarkan hal tersebut telah dilakukan suatu penelitian yang bertujuan untuk megetahui pengaruh pemberian vitamin $\mathrm{E}$ terhadap berat testis, histomorfometri diameter dan ketebalan epitel tubulus seminiferus testis tikus strain Wistar (rattus novergicus) diabetes melitus tipe 1.

Hasil penelitian ini diharapkan dapat meningkatkan pemahaman mengenai mekanisme infertilitas terkait diabetes melitus melalui pendekatan farmakologi. Selain itu juga untuk mengetahui manfaat darivitamin $\mathrm{E}$ terhadap kondisi testis terkait infertilitas yang dicetuskan diabetes melitus sehingga dapat menjadi pertimbangan terhadap tatalaksana dari masalah tersebut.

\section{Metode}

Penelitian dilakukan di Laboratorim Farmakologi Fakultas Kedokteran Hewan Universitas Syiah Kuala Banda Aceh selama 3 bulan yang berlangsung mulai dari 1 Februari 2018 hingga 30 April 2018

Penelitian ini merupakan penelitian eksperimental laboratoris jenis Posttest Only Control Group Design, dengan menggunakan rancangan acak lengkap (RAL) pola satu arah. Tikus dikelompokkan menjadi 4 kelompok perlakuan, masing-masing kelompok terdiri dari 6 ekor tikus. Kelompok $1(\mathrm{KN})$ yaitu tikus tidak diberi perlakuan apapun. Kelompok 2 (KP) yaitu tikus diinjeksi aloksan dosis 125 $\mathrm{mg} / \mathrm{kg}$ BB secara intraperitoneal. Kelompok 3 (P1) yaitu tikus diinjeksi aloksan dosis 125 $\mathrm{mg} / \mathrm{kg}$ BB secara intraperitoneal, kemudian diberi vitamin $\mathrm{E}$ dosis $1,0 \mathrm{mg} / \mathrm{ekor} / \mathrm{hari}$. Kelompok 4 (P2) yaitu tikus diinjeksi aloksan dosis $125 \mathrm{mg} / \mathrm{kg}$ BB, kemudian diberi vitamin E dosis 2,0 mg/ekor/hari. 


\section{Persiapan hewan percobaan}

Sebanyak 30 ekor tikus putih (Rattus Wistar) strain Wistar, berjenis kelamin jantan, berusia 3-4 bulan dengan bobot badan $250-300 \mathrm{~g}$, diperoleh dari Fakultas Kedokteran Hewan Universitas Syiah Kuala, digunakan sebagai sampel pada penelitian ini. Tikus-tikus tersebut diadaptasikan selama seminggu untuk proses aklimasi hewan percobaan dengan lingkungan. Tikus-tikus tersebut ditempatkan dalam kandang yang dirancang khusus berdinding triplek dan kawat kasa serta diperlengkapi dengan tempat air minum dan pakan. Suhu dalam kandang diatur pada suhu kamar dan dipertahankan di bawah kondisi ruang standar pada 12 jam terang / 12 jm gelap dengan suhu $25-27^{\circ} \mathrm{C}$. Selama masa adaptasi tikus-tikus diberi makan berupa pelet sebanyak 20 gram dan air minum diberikan secara ad libitum.

\section{Perlakuan Hewan Coba}

Pada akhir masa adaptasi masing-masing tikus ditimbang untuk mengetahui beratnya digunakan sebagai patokan awal (base line) dalam pengelompokkan tikus untuk perlakuan. Selanjutnya tikus-tikus tersebut dibagi dalam 4 kelompok perlakuan, yaitu kelompok 1 yaitu tikus normal yang tidak diberi perlakuan apapun (KN), kelompok 2 yaitu tikus yang diinjeksikan aloksan dengan dosis 120mg/kgbb (KP). Kelompok 3 yaitu tikus yang diinjeksikan aloksan dengan dosis $120 \mathrm{mg} / \mathrm{kgbb}$ kemudian diberi vitamin E dengan dosis 1,00 mg/ekor/hari (P1). Kelompok 4 yaitu tikus yang diinjeksikan Aloksan dengan dosis $120 \mathrm{mg} / \mathrm{kgbb}$ kemudian diberi vitamin E dosis 2,00 mg/ekor/hari (P2). Perlakuan pemberian vitamin E dilakukan secara oral menggunakan sonde lambung selama 14 hari.

\section{Pengukuran kadar glukosa darah}

Pengukuran kadar glukosa darah tikus dilakukan menggunakan glukometer $\mathrm{Accu}$ Check ${ }^{\circledR}$ Active. Kadar glukosa darah tikus diukur sebanyak 3 kali yaitu sebelum dilakukan penginduksian, setelah 7 hari penginduksian alloxan monohydrate, dan setelah pemberian terapi vitamin E selama 14 hari. Pengukuran glukosa darah dilakukan setelah tikus dipuasakan selama 12-18 jam. Pengambilan darah dilakukan melalui bagian ekor tikus. Ekor tikus dibersihkan terlebih dahulu menggunakan alkohol 70\%. Selanjutnya, digunting ujung ekor tikus hingga darah keluar dari ujung ekor tersebut. Darah yang keluar kemudian diteteskan sebanyak 1 tetes pada strip glukosa yang telah dimasukkan ke dalam glukometer dan ditunggu hingga nilai kadar glukosa darah 
$(\mathrm{mg} / \mathrm{dL})$ tertera pada layar glukometer.

\section{Pengambilan organ testis tikus putih}

Pengambilan organ testis dilakukan dengan pembedahan. Tikus di euthanasia dengan menggunakan kloroform yang dibasahkan pada kapas dan ditempatkan didalam toples.

Setelah beberapa menit tikus diambil dan diletakkan di atas papan dengan posisi dorsal recumbency. Setelah itu tikus dibedah, organ testis dicuci dengan $\mathrm{NaCl}$ fisiologis dan dimasukkan kedalam BNF 10\% selama 24 jam untuk difiksasi.

\section{Pengukuran Berat Testis}

Pengukuran berat testis dilakukan menggunakan timbangan digital, sedangkan pengukuran panjang dan diameter testis dilakukan dengan menggunakan alat ukur jangka sorong.

\section{Pembuatan preparat histologis}

Sediaan testis dalam BNF 10\% selanjutnya dilakukan proses stopping point dalam alkohol $70 \%$ selama 24 jam, lalu dilakukan dehidrasi dengan menggunakan alkohol bertingkat yaitu $70 \%, 80 \%, 90 \%, 95 \%$ dan alkohol absolut. Jaringan kemudian dijernihkan dalam cairan xilol I (selama 1 jam), xilol II (selama 45 menit) dan xilol III (selama 45 menit). Selanjutnya jaringan diinfiltrasi dalam parafin cair dengan tiga kali ulangan yaitu, parafin cair I (selama 1 jam), parafin cair II (selama 45 menit) dan parafin cair III (selama 45 menit). Kemudian dilakukan proses penananamn (embedding) dalam parafin dam dicetak hingga menjadi blok parafin. Jaringan di dalam blok parafin disayat dengan ketebalan 4-5 mikron dan dan irisan diletakkan pada object glass untuk selanjutnya diinkubasikan untuk pembuangan paraffin, selanjutnya diwarnai dengan pewarnaan HE dan diberi perekat entelan (Kiernan, 1990). Teteskan entelan, lalu tutup dengan coverglas dan preparat siap di nilai

\section{Penilaian diameter dan ketebalan epitel tubulus seminiferus testis}

Pengukuran diameter tubulus seminiferus dan ketebalan epitel tubulus seminiferus dilakukan dengan menggunakan alat mikrometer yaitu dengan mengukur antara dua titik yang berseberangan pada garis tengahnya, titik tersebut berada pada membrana basalis tubulus seminiferus. Sedangkan ketebalan epitel tubulus seminiferus dilakukan dengan mengukur antara dinding basal tubulus sampai lumen tubulus seminiferus. Tubulus yang dipilih adalah tubulus yang memiliki penampang bulat dengan ukuran yang kurang 
lebih sama. Hasil pengukuran dinyatakan dalam satuan mikrometer $(\mu \mathrm{m})$.

\section{Analisa Data}

Data berat testis, diameter dan ketebalan epitel tubulus seminiferus pada masing-masing perlakuan dan kelompok kontrol sebelumnya dilakukan analisa normalitas dan homogenitas, jika memenuhi syarat maka dilakukan analisa sidik ragam varian (ANOVA), jika terlihat ada pengaruh maka dilanjutkan dengan uji BNT untuk menilai perbedaan antar perlakuan.

\section{Hasil}

\section{Berat testis dan pengaruh pemberian} vitamin $\mathbf{E}$

Hasil pengukuran berat testes tikus putih (Rattus norvegicus) strain Wistar pada berbagai kelompok perlakuan vitamin $\mathrm{E}$ berbagai dosis selama 14 hari ditunjukkan pada Tabel 1.

Hasil analisis of variance (ANOVA) satu arah terhadap berat testis menunjukan ada perbedaan yang nyata $(p<0,05)$. Hasil ini membuktikan bahwa perlakuan dinduksi aloksan dan pemberian vitamin $\mathrm{E}$ berpengaruh terhadap berat testis tikus putih. Selanjutnya hasil dianalisa Post Hoc dengan uji BNT didapatkan berat testis tikus diabetes yang diberi vitamin $\mathrm{E}$ dosis $200 \mathrm{mg} / \mathrm{kgbb} /$ hari (P2) berbeda secara signifikan dibandingkan dengan tikus diabetes (KP) dengan nilai $\mathrm{p}=0,001$, namun tidak berbeda dibandingkan dengan tikus normal (KN) dengan nilai $\mathrm{p}=0,704$ dan pada tikus diabetes yang diberi vitamin E dosis 100 $\mathrm{mg} / \mathrm{kgbb} / \mathrm{hr}$ dengan nilai $\mathrm{p}=0,596$. Rata-rata berat testis tikus diabetes yang diberi vitamin $\mathrm{E}$ dosis $100 \mathrm{mg} / \mathrm{kgbb} / \mathrm{hr}$ (P1) tidak berbeda dibandingkan dengan tikus normal (KN) dengan nilai $\mathrm{p}=0,879$. Hasil ini membuktikan bahwa pemberian vitamin E dapat meningkatkan berat testis tikus diabetes. Pemberian vitamin E dosis 1,0 mg/ekor/hari tidak berbeda dengan dosis $2,0 \mathrm{mg} / \mathrm{ekor} / \mathrm{hari}$ dalam meningkatkan berat testis tikus diabetes.

\section{Gambaran histologis testis tikus putih}

Hasil pengamatan gambaran histopatologis testis tikus putih normal $(\mathrm{KN})$, tikus yang diberi aloksan (KP), tikus yang diberi aloksan dan Vitamin E dosis $100 \mathrm{mg} / \mathrm{kgbb} / \mathrm{hari}(\mathrm{P} 1)$ dan 200 $\mathrm{mg} / \mathrm{kgbb} / \mathrm{hari}$ (P2) yang diamati dengan pewarnaan HE menggunakan mikroskop cahaya dapat dilihat pada Gambar 1.

Berdasarkan fotomikrograf histopatologis diatas terlihat bahwa ada pengaruh pemberian vitamin E terhadap perubahan struktur 
histologis tubulus seminiferus testis dapat Pada kelompok tikus putih diabetes mellitus diketahui bahwa pada kelompok kontrol yang diberi vitamin $\mathrm{E}$ dosis $1,0 \mathrm{mg} / \mathrm{ekor} / \mathrm{hari}$ negatif $(\mathrm{KN})$ yaitu kelompok tikus putih $\left(\mathrm{P}_{1}\right)$ terlihat tubulus seminiferus dengan normal yang hanya diberi olive iol membrana basalis dan tahapan perkembangan serta susunan sel spermatogenik yang tampak lebih susunan sel spermatogeniknya ke arah lumen tubulus tampak jelas, dan padat. Lumennya terlihat penuh dengan spermatozoa. Asosiasi sel spermatogenik tersusun berlapis sesuai dengan tingkat perkembangannya dari membran jelas daripada kelompok KP, yaitu mempunyai struktur sel spermatogenik yang rapat, padat dan kompak dengan lumen yang lebih sempit berisi spermatozoa dengan struktur yang terlihat jelas berderet menuju lumen. Sel spermatogonia basalis menuju ke arah lumen tubulus yakni spermatogonia, spermatosit, dan spermatid serta lumen tampak terisi penuh oleh spermatozoa. Hal ini menunjukan bahwa proses spermiogenesis berjalan secara normal. Pada kelompok kontrol positif (KP) yaitu tikus yang menderita diabetes terjadi kerusakan pada dinding tubulus seminiferus, walaupun telihat berderet di lamina basalis, lapisan selnya lebih tinggi. Terlihat pula sel Sertoli dan sel Leydig yang nampak besar dan jelas kemungkinan terjadi peningkatan aktivitas fungsionalnya. Hal yang hampir sama juga terlihat pada kelompok perlakuan diabetes mellitus yang diberi vitamin E dosis 2,0 $\mathrm{mg} / \mathrm{ekor} / \mathrm{hari}\left(\mathrm{P}_{2}\right)$ tubulus seminiferus terlihat spermatogonia tampak jelas berderet di lamina basalis tetapi susunan antar sel-sel spermatogeniknya renggang, tidak rapat, jumlah lapisan sel menuju lumen pendek. Lumen tampak lebar dan agak longgar, di dalamnya terdapat sel-sel spermatozoa yang berjumlah sedikit dengan ekor tampak terpisah dengan kepala, antar tubulus seminiferus saling berlekatan. Selain itu juga tampak terdapat ruang-ruang kosong pada tubulus seminiferus.

hampir sama dengan kelompok $\mathrm{KN}$, terlihat susunan sel-sel spermatogeniknya tersusun padat, rapat dan kompak, dengan lumen yang sempit penuh sel spermatozoa. Sel spermatogonianya tampak rapat, spermatosit primernya tampak jelas, sel tampak berkelompok memadat dan besar begitu pula sel sertoli tampak jelas. Pada kelompok $\mathrm{P}_{2}$ lumen terlihat mampat dengan spermatozoa yang tampak jelas struktur kepala dan ekor yang mengarah ke lumen, hal ini berarti semakin tinggi pemberian vitamin $\mathrm{E}$ akan meningkatkan 
aktivitas spermiogenesis.

\section{Histomorfometri Diameter Tubulus Seminiferus Testis}

Diameter tubulus seminiferus merupakan garis tengah tubulus seminiferus yang bulat atau hampir bulat. Pengukuran dilakukan dengan cara menarik garis pada jarak terpendek dan terpanjang yang menghubungkan garis tepi terluar tubulus seminiferus. ${ }^{8,1}$ Hasil histomorfometri menggunakan perangkat lunak Image $J$ menunjukkan diameter tubulus seminiferus kelompok kontrol negatif $(\mathrm{KN})$, tikus diabetes (KP), tikus diabetes yang diberi vitamin $\mathrm{E}$ dosis 1,0 $\mathrm{mg} / \mathrm{ekor} / \mathrm{hari}(\mathrm{P} 1)$ dan tikus diabetes (KP), tikus diabetes yang diberi vitamin $\mathrm{E}$ dosis $2,0 \mathrm{mg} / \mathrm{ekor} /$ hari (P2) dapat dilihat pada tabel 2 .

Tabel 2 menunjukan bahwa rata-rata diameter tubulus seminiferus testes tikus pada perlakuan

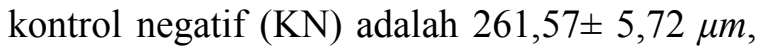
kemudian mengalami penurunan menjadi $241,18 \pm 18,53 \mu m$, pada perlakuan tikus DM yang diinduksi aloksan (KP), dan mengalami peningkatan kembali pada perlakuan tikus DM yang dinduksi aloksan dan vitamin $\mathrm{E}$ dengan dosis $100 \mathrm{mg} / \mathrm{kgbb} / \mathrm{hari}$ (P1), dan 200 $\mathrm{mg} / \mathrm{kgbb} /$ hari (P2), secara berturut-turut adalah $265,92 \pm 15,97 \mu m$ dan $271,41 \pm 24,79 \mu m$.
Hasil analisis of variance (ANOVA) satu arah terhadap diamater tubulus seminiferus testis menunjukan ada perbedaan yang nyata $(\mathrm{p}<0,05)$ diantara kelompok perlakuan. Hasil ini membuktikan bahwa perlakuan dinduksi aloksan dan pemberian vitamin E berpengaruh terhadap diamater tubulus seminiferus testis tikus putih. Selanjutnya hasil dianalisa Post Hoc dengan uji BNT didapatkan diamater tubulus seminiferus testis tikus diabetes yang diberi vitamin E dosis $200 \mathrm{mg} / \mathrm{kgbb} / \mathrm{hari}(\mathrm{P} 2)$ berbeda secara signifikan dibandingkan dengan tikus diabetes $(\mathrm{KP})$ dengan nilai $\mathrm{p}=0,008$, namun tidak berbeda dengan tikus diabetes yang diberi vitamin $\mathrm{E}$ dosis 1,0 mg/ekor/hari (P1) dengan nilai $\mathrm{p}=0,346$ dan tikus normal $(\mathrm{KN})$ dengan nilai $\mathrm{p}=0,596$. Rerata diamater tubulus seminiferus testis tikus diabetes yang diberi vitamin E 1,0 mg/ekor/hari (P1) berbeda secara signifikan dibandingkan dengan tikus diabetes (KP) dengan nilai $\mathrm{p}=0,025$ dan tikus normal (KN) dengan nilai $p=0,674$. Hasil ini menunjukkan bahwa pemberian vitamin $\mathrm{E}$ dosis $1,0 \mathrm{mg} / \mathrm{ekor} / \mathrm{hari}$ dan 2,0 mg/ekor/hari dapat meningkatkan diameter tubulus seminiferus, namun keduanya tidak berbeda dalam meningkatkan diameter tubulus seminiferus testis tikus putih diabetes. 


\section{Histomorfometri Ketebalan Epitel Tubulus}

\section{Seminiferus}

Ketebalan epitel tubulus seminiferus diukur dengan cara menarik garis dari jarak terdekat pada batas antara lapisan sel spermatogonia hingga permukaan lumen setiap tubulus seminiferus. ${ }^{11}$ Hasil pengukuran ketebalan efitel tubulus seminiferus testis tikus putih secara pengamatan histomorfometri dapat dilihat pada Gambar 2.

Fotomikrograf epitel tubulus seminiferus pada Gambar 2. menunjukkan kelompok kontrol tampak tebal dan intak pada membran basalis. Tidak terdapat celah antarsel spermatogenik. Bagian adluminal setiap tubulus seminiferus tampak banyak terdapat spermatozoa. Kelompok perlakuan diabetes menunjukkan terdapat 2 tubulus seminiferus yang epitelnya terlepas dari membran basalis. Spermatozoa pada bagian adluminal tubulus seminiferus yang tidak intak tampak lebih sedikit. Kelompok perlakuan diabetes yang diberi vitamin $\mathrm{E}$ dosis 1,0 mg/ekor/hari (P1) dan dosis 2,0 mg/ekor/hari (P2) menunjukkan epitel pada hampir seluruh tubulus seminiferus tidak intak antarsel spermatogenik. Spermatozoa pada bagian adluminal beberapa tubulus seminiferus tampak lebih sedikit.

Hasil histomorfometri menggunakan perangkat lunak Image $J$ menunjukkan ketebalan epitel tubulus seminiferus testis tikus Rattus norvegicus pada berbagai kelompok perlakuan yang disajikan pada tabel 3 .

Rata-rata ketebalan epitel tubulus seminiferus testis tikus pada perlakuan kontrol negatif $(\mathrm{KN})$ adalah $80,93 \pm 7,33 \mu \mathrm{m}$, kemudian mengalami penurunan menjadi $68,04 \pm 5,73 \mu \mathrm{m}$ pada perlakuan tikus DM yang diinduksi aloksan (KP), dan mengalami peningkatan kembali pada perlakuan P1 dan secara berturut-turut adalah $73,74 \pm 8,53 \mu m$ dan $85,51 \pm 4,34 \mu m$.

Hasil analisis of variance (ANOVA) satu arah terhadap diamater tubulus seminiferus testis menunjukan ada perbedaan yang nyata $(p=0,001)$ diantara kelompok perlakuan. Hasil ini membuktikan bahwa perlakuan dinduksi aloksan dan pemberian vitamin $\mathrm{E}$ berpengaruh terhadap diamater tubulus seminiferus testis tikus putih. Selanjutnya hasil dianalisa Post Hoc dengan uji BNT didapatkan diamater tubulus seminiferus testis tikus diabetes yang diberi vitamin E dosis $200 \mathrm{mg} / \mathrm{kgbb} / \mathrm{hari}(\mathrm{P} 2)$ berbeda secara signifikan dibandingkan dengan tikus diabetes $(\mathrm{KP})$ dengan nilai $\mathrm{p}=0,000$ dan tikus diabetes yang diberi vitamin $\mathrm{E}$ dosis 1,0 $\mathrm{mg} / \mathrm{ekor} / \mathrm{hari}(\mathrm{P} 1)$ dengan nilai $\mathrm{p}=0,006$, namun tidak berbeda dengan dan tikus normal $(\mathrm{KN})$ 
dengan nilai $\mathrm{p}=0,249$. Rerata ketebalan epitel tubulus seminiferus testis tikus diabetes yang diberi vitamin E 1,0 mg/ekor/hari (P1) tidak berbeda secara signifikan dibandingkan dengan tikus diabetes $(\mathrm{KP})$ dengan nilai $\mathrm{p}=0,154$ dan tikus normal $(\mathrm{KN})$ dengan nilai $\mathrm{p}=0,077$. Hasil ini menunjukkan bahwa pemberian vitamin $\mathrm{E}$ dosis 2,0 $\mathrm{mg} /$ ekor/hari dapat meningkatkan ketebalan epitel tubulus seminiferus testis tikus putih diabetes.

\section{Pembahasan}

Penelitian mengenai pengaruh vitamin E terhadap berat testis, diameter tubulus seminiferus dan tebal epitel germinal tubulus seminiferus tikus putih (Rattus novergicus) strain Wistar dengan kondisi diabetes militus telah dilaksanakan. Tikus putih mengalami diabetes militus terjadi setelah mendapatkan pemberian injeksi aloksan dan ditandai dengan terjadinya peningkatan kadar glukosa dalam darah. Hasil pemeriksaan kadar glukosa darah pada penelitian ini menunjukan bahwa rata-rata kadar glukosa darah puasa kelompok tikus normal (KN) pada penelitian ini adalah 99,40 \pm $12,20 \mathrm{mg} / \mathrm{dl}$. Sedangkan pada kelompok tikus putih diabetes yang diinjeksi aloksan, kadar glukosa darah mengalami peningkatan menjadi
$385,17 \pm 17,96 \mathrm{mg} / \mathrm{dl}$. Keadaan ini membuktikan bahwa penyuntikan aloksan dapat meningkatkan kadar glukosa darah, sehingga menyebabkan tikus menderita diabetes. Hal ini sesuai dengan yang dilaporkan Nur $d k k$., kadar glukosa darah tikus diabetes adalah diatas $150 \mathrm{mg} / \mathrm{dl} .{ }^{28}$ Meningkatnya kadar glukosa darah ini disebabkan karena penyuntikan aloksan, menyebabkan kerusakan atau nekrosis sel $\beta$ pankreas sehingga hormon insulin yang dihasilkan kelenjar pankreas menurun dan menimbulkan gangguan homeostasis glukosa. Dengan adanya nekrosis sel $\beta$ pankreas dan penurunan hormon insulin ini maka glukosa dalam darah tidak dapat dipergunakan oleh sel-sel organ tubuh secara sempurna, sehingga kadar glukosa darah dalam tubuh meningkat. ${ }^{29,30}$ Tingginya kadar glukosa darah mendorong lebih banyak donor elektron $\mathrm{NADH}$ dan $\mathrm{FADH}_{2}$ masuk ke dalam rantai transport elektron. Peningkatan laju transport elektron turut berkontribusi dalam pembentukan anion superoksida sehingga terjadi peningkatan reactive oxygen spesies (ROS). ${ }^{31}$ Adanya peningkatan ROS dan tidak diimbangi oleh antioksidan tubuh pada keadaan diabetes menyebabkan terjadinya suatu kondisi yang disebut stress oksidatif. ${ }^{10,12}$ Stress oksidatif tersebut akan mempengaruhi seluruh 
sel tubuh termasuk sel-sel struktural testis (sel Leydig, sel Sartoli dan sel germinal). Stress oksidatif juga menggangu keseimbangan poros hipotalamus-hipofisa-gonad yang akan mempengaruhi kerja Gonadotropin Releasing Hormone (GnRH) sehingga sekresi Follicle Stimulating Hormone (FSH) dan Luteinizing Hormonone (LH) akan terhambat. Bila kondisi ini terus belangsung akan menghambat proses spermatogenesis dan selanjutnya menyebabkan penurunan berat testis. ${ }^{13,14,15}$

Hasil penelitian ini menunjukan rerata berat testes tikus putih yang induksi aloksan (KP) adalah $0,88 \pm 0,18$ gr lebih rendah secara bermakna $(\mathrm{p}<0,05)$ dibandingkan dengan tikus norma $(\mathrm{KN})$ yaitu $1,18 \pm 0,09$ gr. Hasil ini membuktikan bahwa DM akibat induksi aloksan dapat menurunkan berat testis tikus putih, sedangkan pemberian vitamin E dapat menghambat penurunan berat testis tikus putih DM. Hasil ini sesuai dengan dilaporkan oleh beberapa peneliti bahwa pemberian induksi aloksan pada tikus putih mengakibatkan tikus menderita DM yang dikuti dengan terjadi penurunan berat testis. Hasil penelitian Aybek dkk. menunjukan bahwa tikus yang diabetes mengalami penurunan berat testis, kadar testosteron serum dan diameter epididimis secara bermakna dibandingkan dengan tikus nomal. ${ }^{26}$ Penurunan berat testis dapat disebabkan oleh atropi, yaitu suatu proses penyusutan atau berkurang besarnya suatu organ tubuh atau jaringan dari keadaan semula atau dari bentuk normalnya ${ }^{16}$. Berkurangnya ukuran sel disebabkan oleh berkurangnya jumlah sitoplasma dan jumlah organel sitoplasma serta biasanya terkait dengan penurunan metabolisme. Pengurangan jumlah sel disebabkan oleh ketidakseimbangan proliferasi dan kematian sel dalam jangka waktu lama ${ }^{17,18}$. Selain itu menurunnya berat testis tikus putih pada tikus diabetes kemungkinan disebabkan karena induksi aloksan dapat meningkatkan produksi ROS dalam darah, yang selanjutnya dapat menyebabkan kerusakan pada sel $\beta$ pankreas dan gangguan sekresi insulin serta gangguan metabolisme glukosa dalam tubuh. ${ }^{12,15,17}$

Beberapa penelitian menunjukkan bahwa gangguan metabolisme glukosa berhubungan dengan kelebihan produksi ROS. Peningkatan ROS bila tidak mampu dinetralisir oleh enzim antioksidan tubuh dapat menyerang makro molekul sel dan dapat menyebabkan kerusakan membran sel, inti sel dan DNA mitokondria sel, yang selanjutnya terjadi apoptosis sel tubuh 
diantaranya sel-sel interstitial testis seperti sel Sartoli dan sel Leydig. Kerusakan fungsi sel Sertoli dan sel Leydig akan mengganggu proses spermatogenesis. Jika proses spermatogenesis terganggu maka akan mempengaruhi jumlah sel sel germinal yang berada dalam testis. Turunnya jumlah sel Sartoli, sel Leydig dan selsel germinal akan menyebabkan penurunan diameter tubulus seminiferus dan berat testis menjadi berkurang. ${ }^{29,30}$

Hasil penelitian ini juga membuktikan bahwa pemberian vitamin E $1,0-2,0 \mathrm{mg} / \mathrm{kgbb} / \mathrm{hari}$ selama 28 hari pada tikus yang diinduksi aloksan dapat meningkatkan berat testis tikus putih yang menderita DM. Rerata berat testis tikus putih DM yang induksi aloksan (KP) adalah $0,88 \pm 0,18$ gr lebih rendah secara bermakna $(\mathrm{p}=0,001)$ dibandingkan dengan tikus putih DM yang diberi vitamin $\mathrm{E}$ dosis 1,0 $\mathrm{mg} /$ ekor/hari (P1), dan 2,0 mg/ekor/hari (P2) secara berturut-turut adalah $1,17 \pm 0,16$ gr dan $1,21 \pm 0,16$ gr. Terjadinya peningkatan berat testes ini disebabkan vitamin E mampu mencegah kerusakan akitbat peningkatan senyawa oksigen reaktif pada sel-sel Sartoli, Sel Leydig dan sel-sel spermatogenik dalam testis.

Jibiikabi.org
Vitamin E merupakan salah satu vitamin yang bersifat sebagai antioksidan larut dalam lemak yang mampu menghambat aktivitas senyawa oksigen reaktif dan mencegah terjadinya reaksi berantai antara senyawa oksigen reaktif dengan senyawa asam lemak tak jenuh majemuk yang terdapat pada membran plasma sel, dengan carat menyumbangkan satu hidrogen ke radikal lipid peroksil, untuk menghasilkan lipid hidroperoksida dan radikal tokoferoksil pada membran sel. Vitamin E selain bersifat sebagai antioksidan untuk mencegah terjadinya kerusakan sel akibat radikal bebas, juga mampu merangsang pertumbuhan sel-sel Sartoli dan Sel Leydig testis, serta pertumbuhan sel-sel spermatogenik dalam tubuus seminiferus testis. ${ }^{27}$ Hasil ini sesuai dengan pernyataan Chandra dkk bahwa banyaknya kandungan sel Sartoli, sel Leydig dan sel-sel spermatogenik dalam tubulus seminiferus di dalam testis juga dapat meningkatkan berat testis itu sendiri, meskipun masih ada faktor lain yang mempengaruhinya seperti jaringan ikat dan sel-sel otot polos. ${ }^{32}$

Hasil pengukuran rerata diameter tubulus seminiferus testis pada kelompok tikus putih diabetes (KP) adalah 241,18 $\pm 18,53 \mu \mathrm{m}$ lebih rendah secara bermakna dibandingkan dengan 
kelompok tikus putih normal (KN), tikus diabetes yang induksi aloksan dan pemberian vitamin $\mathrm{E}$ dosis 1,0 mg/ekor/hari (P1), dan 2,0 $\mathrm{mg} /$ ekor/hari (P2) secara berturut-turut adalah $261,57 \pm 5,72 \mu m, 265,92 \pm 15,97 \mu m$ dan 271,41 $\pm 24,79 \mu m$ (Tabel.4.6). Hasil ini menunjukkan bahwa tikus putih menderitas diabetes dapat menurunkan diameter tubulus seminiferus, sedangkan pemberian vitamin $\mathrm{E}$ dosis 1,0 $\mathrm{mg} /$ ekor/hari dan 2,0 $\mathrm{mg} / \mathrm{ekor} /$ hari selama 28 hari mampu meningkatkan diameter tubulus seminiferus testis tikus putih diabetes. Menurunnya diameter tubulus seminiferus testis tikus putih diabetes yang diinduksi aloksan (KP) ini diduga karena efek sitotoksik dari aloksan, sehingga sel-sel spermatogenik yang mengisi tubulus seminiferus tidak dapat mempertahankan aktifitasnya. Dengan demikian timbul adanya perbedaan yang bervariasi pada sel-sel spermatogenik di tubulus seminiferus. Tubulus seminiferus merupakan bagian utama dari masa testis (sekitar 80\%) yang merupakan tempat berlangsungnya proses spermatogenesis. Sel-sel endokrin yang mengeluarkan hormon testosteron (sel-sel leydig) terletak dijaringan ikat antar tubulustubulus seminiferus. Sel leydig mengandung enzim yang dibutuhkan untuk sintesis testosteron. Setelah disekresikan tesstosteron yang disekresi diikat oleh ABP (Androgen Binding Protein) yang disekresikan oleh sel Sertoli masuk ke lumen tubulus seminiferus untuk proses spermatogenesis ${ }^{13,34}$. Sejalan dengan hasil penelitian sebelumnya bahwa penurunan yang terjadi pada diameter tubulus seminiferus diduga dikarenakan terhambatnya seksresi LH di hipofisis anterior yang berfungsi untuk menstimulus pertumbuhan dan jumlah sel Leydig, sehingga terjadi penurunan kadar hormon testosteron. Kurangnya kadar hormon testosteron dan FSH inilah yang diduga dapat menyebabkan atropi-atropi tubulus seminiferus ${ }^{30,31}$.

Hasil pengukuran rata-rata ketebalan epitel tubulus seminiferus testis pada kelompok tikus putih diabetes (KP) lebih rendah dibandingkan dengan kelompok tikus putih normal $(\mathrm{KN})$. Hasil pengamatan histopatologi menunjukkan bagian adluminal pada kelompok tikus normal (KN) tampak sel spermatozoa yang lebih banyak pada setiap tubulus seminiferus dibandingkan dengan kelompok tikus diabetes (KP). Epitel tubulus seminiferus pada kelompok tikus putih normal (KN) lebih intak antar sel spermatogenik maupun antara 
membran basalis dengan sel spermatogenik. Sel spermatogenik yang tidak intak antarselnya maupun dengan membran basalis menyebabkan hasil pengukuran histomorfometri ketebalan epitel tubulus seminiferus pada kelompok tikus putih diabetes (KP) lebih rendah dibandingkan kelompok tikus putih normal (KN). Hasil penelitian ini menunjukkan stres oksidatif akibat diabetes berefek terhadap ketebalan epitel dan diameter tubulus seminiferus. Pembatasan kalori tingkat rendah pada diabetes mengakibatkan atrofi tubulus seminiferus dan penurunan diameter tubulus seminiferus. ${ }^{37} \mathrm{Hal}$ tersebut terjadi karena adanya penurunan jumlah sel spermatosit dan sel spermatid yang mengisi epitel tubulus seminiferus. ${ }^{35}$ Pembatasan akses terhadap nutrisi dapat menurunkan ketebalan epitel dan diameter tubulus seminiferus testis. Kurangnya asupan protein menunjukkan seluruh tubulus seminiferus pada kelompok tikus diabetes (KP) memiliki lumen yang luas dan epitel yang tipis dibandingkan dengan tikus normal (KN). Hal ini terjadi karena protein sangat penting dalam mengangkut testosteron masuk ke dalam lumen tubulus seminiferus untuk berlangsungnya spermatogenesis sehingga menghambat maturasi, pertumbuhan dan fungsi organ reproduksi. ${ }^{14,15,16}$
Tubulus seminiferus terdiri dari sel spermatogenik dan sel sertoli. Sel sertoli berfungsi sebagai penunjang, diantaranya menjaga ikatan antarsel sertoli, dengan sel spermatogenik, atau antarsel spermatogenik untuk membentuk sawar darah testis. ${ }^{15,16}$ Sawar darah testis berfungsi meregulasi nutrisi dan faktor pertumbuhan untuk perkembangan sel spermatogenik. Tampak pada fotomikrograf tubulus seminiferus, epitel pada kelompok diabetes tidak intak satu sama lain. ${ }^{32} \mathrm{Hal}$ ini disebabkan karena stres oksidatif merusak taut dan adesi antarsel Sertoli, sel Sertoli dengan sel spermatogenik dan antar sel spermatogenik. Mekanisme yang terjadi adalah melalui aktivasi sinyal phosphatidylinositol 3-kinase (PI3K)focal adhesion kinase (FAK). Phosphatidylinositol 3-kinase yang semula terdapat pada sitosol mengalami translokasi menuju membran sel yang akan meningkatkan permeabilitas membran sel epitel dan sel endotel. Focal adhesion kinase berperan sebagai mediator dalam proses ini. Selain itu, dikarenakan taut antar sel sertoli rusak, maka terjadi kekurangan nutrisi dan faktor pertumbuhan bagi perkembangan sel spermatogenik. ${ }^{23,33}$ Berkurangnya spermatozoa pada bagian adluminal tubulus seminiferus terjadi karena penurunan glukosa dalam tubuh. 
Hal ini mengubah aksis kelenjar hipotalamushipofisis-testis yang menurunkan spermatogenesis. 35,36 Akibatnya, terjadi penurunan berat testis. ${ }^{38}$ Perubahan berat testis dapat merefleksikan perubahan pada tubulus seminiferus yang mengisi $80 \%$ massa testis. ${ }^{39,40}$

\section{Kesimpulan}

Berdasarkan hasil analisis dan pembahasan yang telah diuraikan oleh peneliti, dapat diambil kesimpulan beberapa hal sebagai berikut:

1. Pemberian vitamin E berpengaruh terhadap perbaikan berat testis tikus strain Wistar (rattus novergicus) diabetes melitus tipe 1 .

2. Pemberian vitamin $\mathrm{E}$ berpengaruh terhadap perbaikan perubahan histomorfometri diameter dan ketebalan epitel tubulus seminiferus testis tikus strain Wistar (rattus novergicus) diabetes melitus tipe 1 .

\section{Saran}

1. Diperlukan penelitian lebih lanjut mengenai peran vitamin $\mathrm{E}$ terhadap spermatogenesis tikus putih diabetes militus.
2. Diperlukan penelitian lebih lanjut mengenai peran vitamin $\mathrm{E}$ terhadap biomarker lain yang terkait dengan stress oksidatif dan infertilitas seperti kadar MDA dan aktivitas SOD, Katalase dan Glutation Peroksidase jaringan testis 


\section{Daftar Referensi}

1. Soviana, E., Banundari, R., dan Nyoman, S. W. Pengaruh Suplementasi $\beta$-carotene Terhadap Kadar Glukosa Darah dan Kadar Malondialdehida pada Tikus Sprague dawley yang Diinduksi Streptozotocin. Jurnal Gizi Indonesia 2014;2(2): 41-46.

2. American Diabetes Association. Standards of medical care in diabetes2015. Diabetes Care 38: 1-94

3. International Diabetes Federation. 2015. Diabetes Atlas [serial online] http://www.idf.org/idf-diabetes-atlasseventh-edition. 24 Oktober 2018

4. World Health Organization (WHO). [updated 2017; cited 2017 July 11]. Tersedia fromhttp://www. who.int/topics/diabetes_mellitus/en/.

5. Enzlin P, Mathieu C, Van den Bruel A, Vanderschueren D, Demyttenaere K. Prevalence and Predictors of Sexual Dysfunction in Patients with Type 1 Diabettes . Belgium. Available from : URL :http://www.care. diabetesjournals. org/cgi/content/full/26/2/409; 2003.
6. Russel, S.T., B.K. Khandheria, A. Nehra. Erectile Dysfunction and Cardiovaskular Disease. Rochester Min6 (18 screens). Available from URL http://peereviewedjournal/mayoclinic Proceding. 2004. html

7. Sukawan, U.Y. Gangguan Seksual pada Pria Penderita Diabetes Mellitus. dalam Pertemuan Ilmiah tahunan XIV Perkumpulan Andrologi Indonesia dan Kongres Nasional I Asosiasi Sexolog Indonesia. Buku Acara dan Kumpulan Abstrak. Denpasar. p 15713. 2002.

8. Amaral, S., Oliveira, P. J., and Ramalho, J. Diabetes and the Impairment of Reproductive Function: Possible Role of Mitochondria and Reactive Oxygen Species. Current Diabetes Reviews 2008; 4(1): 46-54.

9. PERKEMI. Konsensus Pengelolaan Diabetes Melitus Tipe 2 di Indonesia 2002. Semarang. 2002; p 6-7.

10. Amaral, S., Moreno, A. J., Santos, M. S., Seica, R., and Santos, J. R. Effects of Hyperglycemia on Sperm and Testicular Cells of Goto-Kakizaki and 
Streptozotocin-Treated Rat Models for

Diabetes. Theriogenology 2006; 66: 2056-2067.

11. Jameel Gulab Jargar, Saeed Yendigeri, Salim Abbasali Dhundasi, Kusal Kanti Das. Protective effect of Vitamin E ( $\alpha$-tocopherol) on nickel-induced alteration of testicular pathophysiology in alloxan-treated diabetic rats . International Journal of Clinical and Experimental Physiology| Oct-Dec 2014 | Vol 1 | pp. 290-296

12. Abd El-Rahim, A. H.; Radwan, H. A.; Abd El-Moneim, O. M.; Farag, I. M. The influence of amaryl on genetic alterations and sperm abnormalities of rats with alloxan-induced hyperglycemia. Journal of American Science, 2010. 6(12):1739-1748.

13. Ballester, J., Munoz, M.C., Dominguez, J., Rigau, T., Guinovart, J.J. and Rodriguez-Gil, J.E. Insulin Dependent Diabetes Affects Testicular Fuction by FSH and LH-Link Mehanism. $J$ Androl. .2004. 25(5) : 706-719.

14. Basmatzou, T. Diabetes Melitus and Influences on Human Fertility.
International Journal of Caring Sciences. 2016. 9(1) : 371-379.

15. Agarwal A, Cocuzza M, Abdelrazik H, Sharma RK. Oxidative stress measurement in patients with male or female factor infertility. Handbook of Chemiluminescent Methods in Oxidative Stress Assessment. 2008. p. 195-218.

16. Maslachah, L., Sugihartuti, R., dan Kurniasanti, R. Hambatan Produksi Reactive Oxygen Species Radikal Superoksida (O2-) oleh Antioksidan Vitamin E ( $\alpha$-Tocopherol) pada TIkus Putih (Rattus norvegicus) yang Menerima Stressor Renjatan Listrik. Media Kedokteran Hewan. 2008; 24(1): 21-26.

17. Darmawan H. Production of ROS and Its Effects on Mitochondrial and Nuclear DNA, Human Spermatozoa, and Sperm Function. Medical Journal Indonesia. 2007.; 16: 2.

18. Adelati, S., Juniarto, A.Z. dan Miranti, I.K. 2016. Histopatologi Spermatogenesis Testis Tikus Wistar Diabetes Melitus. J.K.D. 5(4) : 17601769 
19. Kanter, M., Aktas, C., and Erboga, M. 2012. Protective Affects of Quercetin Against Apoptosis and Oxidative Stress in Streptozotocin-Induced Diabetic Rat Testis. Food Chem Toxicol 50: 719725.

20. Tiwari BK, Pandey KB, Abidi AB, Rizvi SI. Marker oxidative stress during diabetes mellitus. Journal of biomarkers Volume $2013: 378,790$, p1-8.

21. Soudamani S, Malini T, Balasubramanian K. Effects of Streptozotocin-Diabetes and Insulin Replacement on the Epididymis of Prepubertal Rats: Histological and Histomorphometric Studies. Endocrine Research. 2005;31(2):81-98.

22. Agarwal, A., Virk, G., Ong, C. dan Plessis, S. S.D. Effect of Oxidative Stress on Male Reproduction. World $J$ Mens Health, 2014; 32 (1): 1-17.

23. Setiawan B, Suhartono E. Stres Oksidatif dan Peran Antioksidan pada Diabetes Melitus. Majalah Kedokteran Indonesia Pebruari. 2005;55(2).
24. Suarsana IN, I.H. Utama, I.G. Agung dan A. Suartini. 2011. Pengaruh hiperglikemia dan vitamin E pada kadar malonaldehida dan enzim antioksidan intrasel jaringan pankreatikus. Majalah Kedokteran Bandung 43(2):72-6.

25. Haidara MA, Mikhailidis DP, Rateb MA, Ahmed ZA, Yassin HZ, Ibrahim IM, et al. Evaluation of the effect of oxidative stress and vitamin $\mathrm{E}$ supplementation on renal function in rats with streptozotocin-induced Type 1 diabetes. Journal of Diabetes and its Complications. 2009;23(2):130-6

26. Aybek H, Aybek Z, Rota S, Sen N, Akbulut M. The effects of diabetes mellitus, age, and vitamin $\mathrm{E}$ on testicular oxidative stress. Fertil Steril. 2008 Sep; 90(3):755-60. PMID: 17482598

27. Keskes-Ammar L, Feki chakroun N, Rebat T, et al. Sperm Oxidative Stress and the Effect of an Oral Vitamin E and Selenium Supplement on Semen Quality in Infertile Men. Syst Biol Reprod Med. 2003;49(2):83-94. doi: 10.1080/01485010390129269. 
28. Nur, S.M., Awaloei, H. dan Wuisan, J. Uji efek air perasan albedo semangka kuning (Citrilus lanatus (Thunb.) Matsum. \& Nakai) terhadap kadar glukosa darah pada tikus wistar (Rattus norvegicus) yang diinduksi aloksan. Jurnal e-Biomedik (eBm). 2016. 4(1): 17.

29. Coskun O, Ocakci Ayse, Bayraktaroglu $\mathrm{T}$, and Kanter M. Exercise Training Prevents and Protects StreptozotocinInduced Oxidative Stress and $\beta-C e l l$ Damage in Rat Pancreas. Departement of Medical Histology and Embryology. Turkey: Zonguldak Karaelmas University. 2004

30. Maneesh,M., Jayalaksmi, H., Singh, T.A. dan Cakrabhati, A. Impaired Hipothalami-Pituitary-Gonadal axist function in men with diabetes melitus. Indian Journal of Clinichal Biochemistry. 2006. 21(1):165-166.

31. Mitayani. 2009. Pengaruh Pemberian Ekstrak Pare (Momordica charantia L) Terhadap Jumlah Spermatozoa, Diameter Tubulus Seminiferus dan Berat Testis Tikus Jantan Strain
Wistar Sebagai Bahan Kontrasepsi Alamiah. Tesis Unpad

32. Apriliani, M., Nurcahayani, N. dan Busman, H.Efek Pemaparan Kebisingan terhadap Jumlah Selsel Spermatogenik dan Diameter Tubulus Seminiferus Mencit (Mus musculus L.). Lembaga Penelitian Universitas Lampung. 2013.

33. Sulistyoningrum, E., Setiawati., Nindyastuti, H. dan Putra, A.N. Infusa Daging Buah Mahkota Dewa Memperbaiki Kerusakan Testis dan Parameter Sperma Tikus Diabetik. Jurnal Sains Medika, 2012; 4 (2): 115123.

34. Abdulgani, N dan Maharani, L. Potensi Regenerasi Sel Leydig dan Sel Spermatogenik pada Testis Mencit Mencit (Musmusculus) Hiperglikemik yang Diinduksi dengan Ekstrak IkanGabus (Channa striata). Tugas Akhir. Surabaya: ITS.2014.

35. Fatani, A. J., Al-Rejale, S., Abuohashish, H. M., Al-Assaf, A., Parmar, M. Y., and Ahmed, M. M. 2015. Lutein Dietary Supplementation Attenuates 
Streptozotocin-induced Testiscular

Damage and Oxidative Stress in

Diabetic Rats. BMC Complementary and Alternative Medicine 15:204

36. Kianifard D, Sadrkhanlou RA, Hasanzadeh S. The ultrastructural changes of the sertoli and leydig cells following streptozotocin induced diabetes. Iran J Basic Med Sci 2012;15:623-35.

37. Sanguinetti RE, Ogawa K, Kurohmaru M, Hayashi Y. Ultrastructural changes in mouse Leydig cells after streptozotocin administration. Exp Anim 1995;44:71-3.

38. Oztürk F, Gül M, Agkadir M, Yagmurca M. Histological alterations of rat testes in experimental diabetes. $\mathrm{T}$ Kin J Med Sci 2002;22:173-8.

39. Palmeira, C. M., Santos, D. L., Seica, R., Moreno, A. J., andSantos, M. S. Enhanced Mitochondrial Testicular Antioxidant Capacity in Goto-Kakizaki Diabetic Rats: Role of Coenzyme Q. Am J Physiol Cell Physiol. 2001: 281: 1023-1028.

40. Shayakhmetova, G. M., Bondarenko, L. B., and Kovalenko, V.M. Damage of Testicular Cell Macromolecules and Reproductive Capacity of Male Rats Following Co-Administration of Ethambutol, Rifampicin, Isoniazid Acid and Pyrazinamide. Interdiscip Toxicol, 2012:5(1): 9-14. 
Tabel 1. Data rataan ( \pm SD) berat testis tikus Rattus norvegicus

\begin{tabular}{ccc}
\hline Perlakuan & Ulangan & Rataan Berat Testis (mg) \\
\hline KN & 5 & $1,18 \pm 0,09^{\mathrm{a}}$ \\
KP & 5 & $0,88 \pm 0,18^{\mathrm{b}}$ \\
P1 & 5 & $1,17 \pm 0,16^{\mathrm{a}}$ \\
P2 & 5 & $1,21 \pm 0,16^{\mathrm{a}}$ \\
\hline
\end{tabular}

Ket: Superskrip yang berbeda pada kolom yang sama menunjukan perbedaan yang nyata $(\mathrm{P}<0.05)$.

$\mathrm{KN}=$ Kelompok tikus normal yang tidak mendapatkan perlakuan

$\mathrm{KP}=$ Kelompok tikus putih diebets

$\mathrm{P} 1=$ Kelompok tikus putih diabetes yang diberi vitamin $\mathrm{E} 1,0 \mathrm{mg} / \mathrm{ekor} / \mathrm{hari}$

P2 = Kelompok tikus putih diabetes yang diberi vitamin E 2,0 mg/ekor/hari
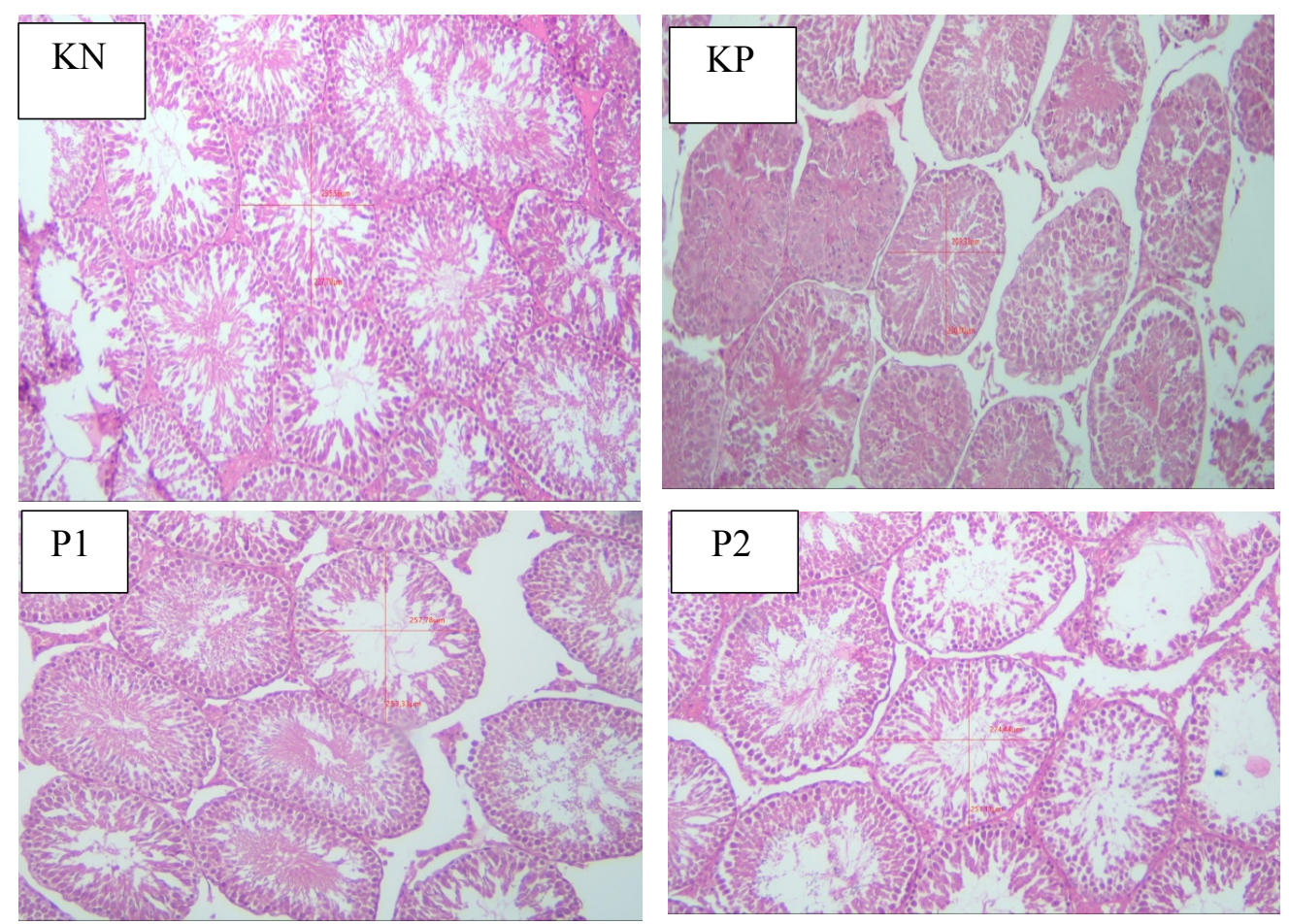

Gambar 1 Fotomikrograf histopatologis testis tikus putih strain Wistar pada kontrol Negatif $(\mathrm{KN})$, Kontrol Positif (KP), Perlakuan 1 (P1) dan Perlakuan 2 (P2) dengan pewarnaan HE dan pembesaran 40x. 
Tabel 2 Data rataan $( \pm \mathrm{SD})$ diamater tubulus seminiferus testes tikus Rattus norvegicus

\begin{tabular}{ccc}
\hline Perlakuan & Ulangan & $\begin{array}{c}\text { Diamater tubulus } \\
\text { seminiferus Testis }(\boldsymbol{\mu m})\end{array}$ \\
\hline KN & 5 & $261,57 \pm 5,72$ \\
KP & 5 & $241,18 \pm 18,53$ \\
P1 & 5 & $265,92 \pm 15,97$ \\
P2 & 5 & $271,41 \pm 24,79$ \\
\hline
\end{tabular}

Ket: Superskrip yang berbeda pada kolom yang sama menunjukan perbedaan yang nyata $(\mathrm{P}<0.05)$.

$\mathrm{KN}=$ Kelompok tikus normal yang tidak mendapatkan perlakuan

$\mathrm{KP}=$ Kelompok tikus putih diebets

$\mathrm{P} 1=$ Kelompok tikus putih diabetes yang diberi vitamin $\mathrm{E} 1,0 \mathrm{mg} / \mathrm{ekor} / \mathrm{hari}$

P2 = Kelompok tikus putih diabetes yang diberi vitamin E 2,0 mg/ekor/hari
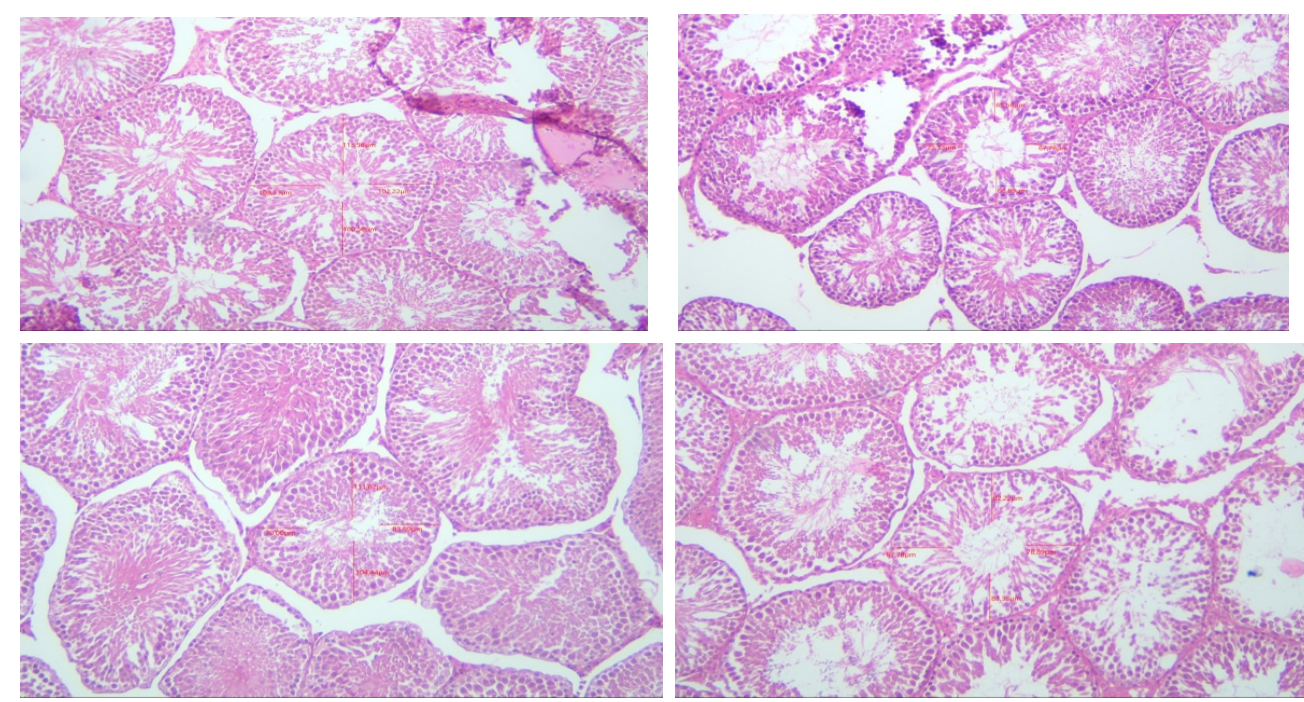

Gambar 2. Fotomikrograf histomorfometri ketebalan epitel tubulus seminiferus testis tikus putih strain Wistar pada Perlakuan Kontrol Negatif (KN), Kontrol Positif(KP), Perlakuan Vit. E 1,0 mg/ekor/hari (P1) dan Perlakuan Vit. E 2,0 mg/ekor/hari (P2) dengan pewarnaan HE pada pembesaran 40x 
Tabel 3. Data rataan ( \pm SD) ketebalan epitel tubulus seminiferus testes tikus Rattus norvegicus

\begin{tabular}{ccc}
\hline Perlakuan & Ulangan & $\begin{array}{c}\text { ketebalan epitel tubulus } \\
\text { seminiferus }(\boldsymbol{\mu m})\end{array}$ \\
\hline KN & $\mathbf{5}$ & $80,93 \pm 7,33$ \\
KP & $\mathbf{5}$ & $68,04 \pm 5,73$ \\
P1 & $\mathbf{5}$ & $73,74 \pm 8,53$ \\
P2 & $\mathbf{5}$ & $85,51 \pm 4,34$ \\
\hline
\end{tabular}

Ket: Superskrip yang berbeda pada kolom yang sama menunjukan perbedaan yang nyata $(\mathrm{P}<0.05)$.

$\mathrm{KN}=$ Kelompok tikus normal yang tidak mendapatkan perlakuan

$\mathrm{KP}=$ Kelompok tikus putih diebets

$\mathrm{P} 1=$ Kelompok tikus putih diabetes yang diberi vitamin $\mathrm{E} 1,0 \mathrm{mg} / \mathrm{ekor} / \mathrm{hari}$

P2 = Kelompok tikus putih diabetes yang diberi vitamin E 2,0 mg/ekor/hari 